\title{
LA MOCIÓN DE CENSURA AL ALCALDE A LA LUZ DE LA JURISPRUDENCIA CONSTITUCIONAL (COMENTARIO A LA STC 151/2017, DE 21 DE DICIEMBRE)'
}

\author{
The motion of censure to the mayor in the light \\ of constitutional jurisprudence \\ (Comment to STC 151/2017, of December 21)
}

\author{
ANTONIO ARROYO GIL \\ Universidad Autónoma de Madrid \\ antonio.arroyo@uam.es \\ Cómo citar/Citation \\ Arroyo Gil, A. (2019). \\ La moción de censura al alcalde a la luz de la jurisprudencia constitucional \\ (Comentario a la STC 151/2017, de 21 de diciembre). \\ Revista Española de Derecho Constitucional, 116, 329-363 \\ doi: https://doi.org/10.18042/cepc/redc.116.11
}

\section{Resumen}

Análisis crítico de la STC 151/2017 en la que se aborda la situación en que se encuentran los concejales no adscritos en la promoción y votación de la moción de censura al alcalde, la diferencia entre estos y los concejales tránsfugas de acuerdo con la legislación vigente y el «acuerdo político antitransfuguismo», así como la incidencia de la regulación existente a este respecto sobre el derecho fundamental a la participación política en su dimensión pasiva previsto en el art. 23.2 CE.

1 El presente trabajo se enmarca dentro del proyecto de investigación del «Programa estatal de fomento de la investigación científica y técnica de excelencia del Ministerio de Economía y Competitividad» (DER2016-78391-P) sobre «El control de constitucionalidad de la ley: constitucional, comunitario y convencional» (IP 1: César Aguado Renedo / IP 2: Antonio López Castillo). 


\title{
Palabras clave
}

Moción de censura; concejal no adscrito; tránsfuga; derecho de participación política; alcalde; ayuntamiento; inconstitucionalidad; nulidad

\begin{abstract}
Critical analysis of the STC 151/2017 in which it is judged the situation in which are the councilors not assigned in the promotion and voting of the motion of censure to the mayor, the difference between these and the defectors councilors in accordance with the legislation in force and the Political Agreement against Defection, as well as the incidence of the existing regulation in this regard on the fundamental right to political participation in its passive dimension foreseen in art. 23.2 CE.
\end{abstract}

Keywords

Motion of censure; councilor not attached; defector councilor; right of political participation; mayor; town hall; unconstitutionality; nullity. 


\section{SUMARIO}

I. INTRODUCCIÓN: CONTEXTO NORMATIVO, JURISPRUDENCIAL Y POLÍTICO AL TIEMPO DE DICTARSE LA STC 151/2017. II. ANTECEDENTES DE LA STC 151/2017. III. FUNDAMENTOS JURÍDICOS DE LA STC 151/2017: 1. La dimensión pasiva del derecho fundamental de participación política del art. 23.2 CE y la moción de censura al alcalde. 2. La inconstitucionalidad, con nulidad diferida, del art. 197.1.a) párr. tercero LOREG. IV. VALORACIÓN CRÍTICA DE LA STC 151/2017. V. CONCLUSIÓN. BiBLIOGRAFÍA.

\section{INTRODUCCIÓN: CONTEXTO NORMATIVO, JURISPRUDENCIAL Y POLÍTICO AL TIEMPO DE DICTARSE LA STC 151/2017}

En consonancia con nuestra forma de gobierno parlamentaria, el título $\mathrm{V}$ de la Constitución española regula las relaciones entre el Gobierno y las Cortes Generales. En concreto, el art. $113 \mathrm{CE}$ prevé la posibilidad de que el Congreso de los Diputados pueda exigir la responsabilidad política del Gobierno mediante la adopción por mayoría absoluta de la moción de censura, que podrá ser propuesta, al menos, por un décimo de los diputados, y siempre que se incluya un candidato alternativo a la presidencia del Gobierno, nota esta que es propia del parlamentarismo racionalizado de inspiración germánica, como lo es el nuestro ${ }^{2}$. Al tratarse de una moción constructiva, mediante la misma no solo se cumple con aquella facultad, la de controlar y exigir responsabilidad política del Gobierno, sino que también a través de ella se procede, por una vía que se puede caracterizar de extraordinaria, a la elección e investidura de un nuevo presidente del Gobierno, tal y como dispone el art. 114.2 $\mathrm{CE}^{3}$.

La Constitución no prevé algo así en el ámbito local. Sin embargo, ya una ley preconstitucional que regulaba las elecciones locales (Ley 39/1978, de 17 de julio), contemplaba, en relación con las diputaciones provinciales, la posibilidad de que su presidente pudiera ser «destituido de su cargo por

2 La bibliografía a este respecto es muy amplia. Valga por todos, Vírgala Foruria (1988); Elías Méndez (2005); Simón Yarza (2015), y Torres Muro (2017).

3 Y según se ha podido comprobar en la última de las tres mociones de censura presentadas en España, con la investidura de Pedro Sánchez como presidente del Gobierno, el 1 de junio de 2018. 
acuerdo de la Corporación, adoptado por las dos terceras partes del número de Diputados» (art. 34.3)

Esta previsión legal, sin embargo, solo se refería a las diputaciones provinciales, sin que existiera una regulación similar en relación con los municipios, lo que fue considerado por la jurisprudencia constitucional como una laguna (STC 5/1983, de 4 de febrero, y ATC 52/1983, de 9 de febrero). Ante esta situación, los tribunales de lo contencioso-administrativo entendieron que en el ámbito del Gobierno municipal también cabía la moción de censura a los alcaldes por parte de los concejales, aplicando analógicamente la normativa referida que regulaba tal cuestión en relación con los presidentes provinciales, con apoyo en el principio del contrarius actus, de forma que sostuvieron que quien es competente para elegir al alcalde también lo es para destituirlo (SSTS de 14 de julio de 1983; 27 de marzo y 10 de octubre de 1984).

Posteriormente, el legislador básico del régimen local incluyó esta facultad de control y exigencia de responsabilidad tanto en relación con el alcalde como con el presidente provincial [arts. 22.3 y 33.3 Ley 7/1985, de 2 de abril, reguladora de las Bases del Régimen Local (LRBRL) $]^{5}$, si bien se remitía a lo que a tal efecto dispusiera la legislación de régimen electoral general para la regulación del régimen jurídico de dichas mociones de censura ${ }^{6}$, cosa que

4 Un breve, pero muy claro y ordenado, resumen de la normativa y jurisprudencia que ha llevado a la introducción de la moción de censura en el ámbito local y sus modificaciones, con el fin, primordialmente, de combatir el obstruccionismo y el transfuguismo, en Ortega Montoro (2018).

5 Los estudios sobre la introducción de la moción de censura local en el ordenamiento jurídico español son muy numerosos. Valga por todos Rebollo Puig (1985). Años más tarde, se mostró muy crítico con el rendimiento de este instrumento Santolaya Machetti (2001).

6 La Constitución no preveía si la regulación de las elecciones locales había de llevarse a efecto por medio de ley orgánica u ordinaria. Fue el Tribunal Constitucional el que en su Sentencia 38/1983, de 16 de mayo (FJ 2), concluyó que las elecciones locales se incluían en el régimen electoral general, que según el art. $81 \mathrm{CE}$ ha de ser regulado por medio de ley orgánica. Es así como en la LOREG se regula esta cuestión, junto con la moción de censura y la cuestión de confianza, en tanto que ambas instituciones afectan al acceso, permanencia y cese en el cargo de los alcaldes. Una y otra son el mejor ejemplo de la forma de gobierno de naturaleza parlamentaria propia de nuestro régimen local, en el que, no obstante, se encuentra muy reforzada la figura del alcalde, con algunos rasgos de carácter ciertamente presidencialista, dada la posición de liderazgo político que asume. Esto, sin embargo, no nos puede llevar a ignorar que, a diferencia de lo que sucede a nivel estatal, «en el sistema de gobierno local no cabe el mecanismo de la disolución anticipada del Pleno del Ayuntamiento por el 
efectivamente sucedió meses más tarde con la aprobación de la Ley Orgánica 5/1985, de 19 de junio, del Régimen Electoral General (LOREG), que en su art. 197 regula tal cuestión ${ }^{7}$.

En su primigenia redacción, este precepto preveía la posibilidad de destituir al alcalde de su cargo mediante moción de censura adoptada por la mayoría absoluta del número de concejales, exigiendo, con carácter previo, que la misma fuera suscrita, al menos, por la tercera parte de los mismos, y que incluyera el nombre del candidato propuesto para alcalde, quien quedaría proclamado como tal en caso de prosperar la moción.

Años más tarde, esta regulación se vio «endurecida» con motivo de la reforma de la LOREG mediante la Ley Orgánica 8/1991, de 13 de marzo. A partir de ahora, se exige que la moción sea suscrita, al menos, por la mayoría absoluta de los concejales, y que la misma sea votada en un Pleno convocado a tal efecto en el plazo de quince días desde su presentación.

Ante la falta de efectividad de estas medidas para evitar sustituciones de alcaldes como consecuencia del planteamiento de una moción de censura suscrita y votada por concejales pertenecientes al mismo grupo político del alcalde o que hubieran abandonado su grupo de origen, que aun no siendo muy numerosas, sí provocaban un gran eco mediático y malestar ciudadano, el 7 de julio de 1998 se suscribió por parte del Ministerio de Administraciones Públicas y los principales partidos políticos un código de conducta política, el llamado "pacto o acuerdo antitransfuguismo» ${ }^{8}$ (que dos años más tarde, el 26 de septiembre de 2000, se vería renovado). Mediante el mismo se pretendía poner freno a tales prácticas, que se consideraban nocivas para la confianza de los ciudadanos en las instituciones locales representativas, en la medida en que podían acabar desestabilizando o provocando cambios en los Gobiernos municipales

alcalde y la convocatoria de nuevas elecciones locales, salvo en el supuesto excepcionalísimo de los artículos 61 LBRL y 183 LOREG». Véase Delgado del Rincón (2012: 335, 339 y ss.).

7 Sobre la controvertida base competencial del Estado para regular esta cuestión por medio de la LOREG, véase el comentario a la STC 81/2012, de 18 de abril (y al voto particular del magistrado Luis Ortega al que se adhiere el magistrado Javier Delgado), realizado por Delgado del Rincón (2012: 352 y ss.). En su opinión, «a la regulación de la moción de censura al alcalde son aplicables los títulos competenciales estatales del artículo 149.1.18 y del 149.1.1 CE».

8 Su denominación completa es "Acuerdo sobre un código de conducta política en relación con el transfuguismo en las corporaciones locales», suscrito el 7 de julio de 1998. Un estudio de su gestación y contenido en De la Torre Martínez (2014: 18 y ss.). Véase asimismo Català i Bas (2014). 
susceptibles de ser considerados como un fraude de la voluntad popular. Las medidas que constituyen el contenido de dichos acuerdos son muy variadas, si bien su valor es meramente político ${ }^{9}$. Entre otras cosas, se preveía llevar a efecto una reforma de la LOREG orientada a tal objetivo ${ }^{10}$, pero lo cierto es que esta no llegó a producirse en los términos acordados en el pacto.

Por el contrario, la modificación de esta norma, llevada a efecto a través de la Ley Orgánica 8/1999, de 21 de abril, se tradujo tan solo en la introducción de la cuestión de confianza en el ámbito local, así como en la incorporación de una regulación más exigente, precisa y detallada del régimen jurídico de la moción de censura, con el fin primordial de evitar prácticas destinadas a dificultar o entorpecer su normal desarrollo por parte del alcalde censurable, como, por ejemplo, la no convocatoria del Pleno que debe discutirla y votarla. Entre otras cosas, en esta nueva normativa se establece que una vez propuesta la moción por, al menos, la mayoría absoluta del número legal de concejales ${ }^{11}$,

9 Entre ellas, interesa destacar la siguiente: «3. ${ }^{\circ}[\ldots]$ los partidos firmantes propiciarán las reformas reglamentarias en las Corporaciones Locales donde ostenten representación, con la finalidad de aislar a los concejales tránsfugas. Los nuevos reglamentos establecerán que los concejales que abandonen los partidos o agrupaciones en cuyas candidaturas resultaron elegidos no pasen al Grupo Mixto, sino que se organicen a partir de la creación de la figura de los "No Inscritos" o del "Concejal Independiente" con la creación, en su caso, del correspondiente grupo de "no inscritos" y actúen en la corporación de forma aislada, sin que puedan percibir o beneficiarse de los recursos económicos y materiales puestos a disposición de los grupos políticos de la corporación».

10 En concreto, los partidos políticos firmantes del acuerdo asumieron los compromisos de «estudiar y, en su caso, presentar, antes de finalizar el próximo período de sesiones, una iniciativa legislativa de reforma de la Ley Orgánica del Régimen Electoral General, para regular el supuesto de titularidad del cargo cuando el representante electo abandone voluntariamente el partido político» (punto 4. ${ }^{\circ}$ ), así como «una iniciativa de reforma de la Ley Orgánica del Régimen Electoral General que limite los efectos del transfuguismo que pueda provocar la presentación de mociones de censura.

En este sentido se considerará la posibilidad de que la regulación incluya:

- La imposibilidad de presentar mociones de censura antes de transcurrido un año desde la toma de posesión de la presidencia de la corporación o durante el último año de mandato.

- Que será requisito previo para los concejales que abandonen su grupo de origen, la permanencia, al menos durante un año, en otro grupo político, para que puedan suscribir durante su mandato una moción de censura" (punto 6..$^{\circ}$ ).

11 Como bien aprecia Delgado del Rincón (2012: 346 y ss.), esta modificación «supone también un endurecimiento del requisito, pues el número legal de concejales puede no coincidir con el número de hecho». 
se deberá convocar de manera automática el Pleno para las 12 horas del décimo día hábil siguiente al de su registro, ostentando la presidencia del mismo una mesa de edad, procediéndose después a su votación, y prosperando la misma cuando vote a su favor la mayoría absoluta del número legal de miembros del Ayuntamiento.

Con idéntica fecha, tuvo lugar una reforma de la LRBRL mediante la Ley 11/1999, de 21 de abril, en virtud de la cual se incluyó un apdo. 3 en el art. 73, del siguiente tenor: «A efectos de su actuación corporativa, los miembros de las Corporaciones locales se constituirán en grupos políticos, en la forma y con los derechos y obligaciones que se establezcan». De este modo, los grupos políticos pasan a convertirse en la pieza central de la organización y funcionamiento de las corporaciones locales ${ }^{12}$, lo que, como veremos seguidamente, tiene gran relevancia en relación con la moción de censura.

Unos años más tarde fue modificado, de nuevo, el art. 73.3 LRBRL, mediante la Ley 57/2003, de 16 de diciembre, de medidas para la modernización del Gobierno local. En concreto, a los efectos que aquí nos interesan, esta modificación supuso la introducción de la figura de los llamados «miembros no adscritos»: aquellos que no se integren «en el grupo político que constituya la formación electoral por la que fueron elegidos o que abandonen su grupo de procedencia». Además, en su último párrafo, este precepto prevé que "cuando la mayoría de los concejales de un grupo político municipal abandonen la formación política que presentó la candidatura por la que concurrieron a las elecciones o sean expulsados de la misma, serán los concejales que permanezcan en la citada formación política los legítimos integrantes de dicho grupo político a todos los efectos». Efectos que, por lo que se refiere al ejercicio de los derechos económicos y políticos, se encuentra regulado en el Reglamento Orgánico de cada corporación.

Los intentos de continuar en esta línea política de evitación o limitación de los efectos que para la estabilidad de los Gobiernos municipales provocan las prácticas de transfuguismo explican que el 23 de mayo de 2006 se

12 En realidad, la regulación de los grupos políticos se había introducido ya hace años por medio del Real Decreto 2568/1986, de 28 de noviembre, por el que se aprueba el Reglamento de Organización, Funcionamiento y Régimen Jurídico de las Entidades Locales (conocido como ROF). En su capítulo II (arts. 23 a 29), al tiempo que se establece su régimen jurídico básico, se dispone que los miembros de las corporaciones locales habrán de constituirse en grupos a efectos de su actuación corporativa, sin que nadie pueda pertenecer simultáneamente a más de un grupo (art. $23 \mathrm{ROF}$ ). 
renovara el acuerdo político a través de la conocida II adenda, incluyendo en ella, entre otras cosas, una definición de "tránsfuga»" ${ }^{13}$.

Cinco años después, a través de la Ley Orgánica 2/2011, de 28 de enero, se aprobó una nueva reforma del art. 197 LOREG, de la que cabe destacar lo siguiente: se mantiene la necesidad de que la moción de censura sea propuesta, al menos, por la mayoría absoluta del número legal de miembros de la corporación, y que se incluya un candidato a la alcaldía, si bien se introducen dos importantes condiciones adicionales en los párrs. segundo y tercero del apdo. 1.a), con el fin de continuar dificultando las prácticas de transfuguismo, que atacan directamente al corazón del sistema democrático representativo, en tanto que ponen en riesgo la estabilidad municipal y tratan de modificar la voluntad popular.

De acuerdo con el párr. segundo del art. 197.1.a) LOREG: «En el caso de que alguno de los proponentes de la moción de censura formara o haya formado parte del grupo político municipal al que pertenece el Alcalde cuya censura se propone, la mayoría exigida en el párrafo anterior se verá incrementada en el mismo número de concejales que se encuentren en tales circunstancias».

Y de conformidad con el párrafo tercero: «Este mismo supuesto será de aplicación cuando alguno de los concejales proponentes de la moción haya dejado de pertenecer, por cualquier causa, al grupo político municipal al que se adscribió al inicio de su mandato».

Así pues, a tenor de esta nueva regulación, cuando la moción de censura sea suscrita por algún concejal que «formara o haya formado parte del grupo político municipal al que pertenece el Alcalde» o que «haya dejado de pertenecer, por cualquier causa, al grupo político municipal al que se adscribió al inicio de su mandato", su apoyo a la moción motivará, ope legis, una elevación del número de concejales necesarios para proponerla.

Este «quórum de procedibilidad» debe cumplirse no solo en el momento de presentación de la moción, según acabamos de ver, sino también al tiempo

13 Son considerados tales «los representantes locales que, traicionando a sus compañeros de lista y/o de grupo - manteniendo estos últimos su lealtad con la formación política que los presentó en las correspondientes elecciones locales-, o apartándose individualmente o en grupo del criterio fijado por los órganos competentes de las formaciones políticas que los han presentado, o habiendo sido expulsados de éstas, pactan con otras fuerzas para cambiar o mantener la mayoría gobernante en una entidad local, o bien dificultan o hacen imposible a dicha mayoría el gobierno de la entidad. Cuando surgiesen dudas sobre qué miembros de una lista y/o grupo político han incurrido en transfuguismo, será la formación política que los ha presentado la que deberá aclarar por escrito cuáles de ellos se han apartado de la disciplina de partido, a efectos de su calificación como tránsfugas». 
de la celebración del Pleno en que la misma se ha de votar, correspondiendo a la mesa de edad que lo presida constatar tal cosa, según dispone el apdo. e) del susodicho art. 197.1 LOREG.

Igualmente relevante es que con esta reforma de 2011 se suprime el apdo. f) de este precepto, que disponía que «el candidato incluido en la moción de censura quedará proclamado Alcalde si ésta prosperase con el voto favorable de la mayoría absoluta del número de concejales que legalmente componen la Corporación». De lo que cabe deducir que a partir de ahora la moción de censura prosperará simplemente con que vote a favor de ella la mayoría simple de los concejales que participen en la sesión correspondiente, dado que según el art. 47.1 LRBRL esta es la regla general. Lo que se ve corroborado por el hecho de que no otra cosa se dispone en el apdo. 2 de este precepto, que es el que requiere el voto favorable de la mayoría absoluta del número legal de miembros de las corporaciones para la adopción de acuerdos en las materias que el mismo enumera, entre las que no se encuentra la votación de una moción de censura $^{14}$.

De este modo, las medidas legislativas adoptadas en 2011 con el fin de continuar combatiendo el transfuguismo son de sentido contradictorio, pues si por un lado se endurece el llamado "quórum de procedibilidad", por el otro se suaviza el de votación, sin que se alcance bien a comprender por qué15.

Sea como fuere, esta es la regulación vigente en el momento en que la Sección segunda de la Sala de lo Contencioso-Administrativo del Tribunal Superior de Justicia de Canarias, con sede en Santa Cruz de Tenerife, plantea

14 Así fue reconocido en el Acuerdo 45/2014, de 20 de marzo, de la Junta Electoral Central, en donde esta sostiene expresamente que "para la aprobación de la moción de censura basta con que los votos favorables sean superiores a los contrarios, al no exigir la LOREG ninguna mayoría cualificada». En sentido similar, en el Acuerdo 202/2014, de 15 de julio, la Junta Electoral Central, con motivo de la «Consulta de la Comisión Gestora del Municipio de Valderrubio (Granada) sobre si podría el Reglamento Orgánico de la Corporación exigir una mayoría cualificada para que prospere la moción de censura contra un Alcalde, desaparecida del art. 197.1 de la LOREG la exigencia de mayoría cualificada en la votación», literalmente considera que «resulta contrario a los principios de legalidad y de jerarquía normativa consagrados en el artículo 9.3 de la Constitución, así como al principio de reserva legal de esta materia (artículo 9.3 y 81.1 de la Constitución), que un Reglamento municipal modifique lo dispuesto en la Ley Orgánica de Régimen Electoral General». Véase, asimismo, Sámnchez y Lomo (2017).

15 Un estudio sistemático — y crítico- del complejo procedimiento de la moción de censura en el ámbito local (presentación, tramitación y votación) en Sánchez y Lomo (2017). 
la cuestión de inconstitucionalidad núm. 5210/2014, respecto del art. 197.1.a) párr. tercero en relación con el párr. segundo de la LOREG, por posible vulneración del art. 23.2 CE. Cuestión que resuelve la Sentencia 151/2017, de 21 de diciembre, objeto del presente comentario.

\section{ANTECEDENTES DE LA STC 151/2017}

Resumidos de manera muy sucinta, y centrándonos tan solo en aquellos aspectos relevantes para el presente comentario, estos son los antecedentes que dieron lugar a la STC 15/2017: tras las elecciones locales celebradas el 22 de mayo de 2011, el 11 de junio tuvo lugar la sesión pública de constitución del Ayuntamiento de Tacoronte (Tenerife), siendo proclamado alcalde-presidente de la corporación local don Álvaro Agustín Dávila González (de Coalición Canaria-PNC), con trece votos a favor de los veintiún miembros electos. Se constituyeron cuatro grupos políticos: Coalición Canaria-PNC (con siete concejales), Grupo Popular y Grupo Socialista (con seis concejales cada uno) y Grupo Municipal Mixto (con dos concejales de la candidatura de Alternativa Sí se puede por Tenerife).

El 11 de octubre de 2013, once concejales (los seis del Grupo Popular y cinco del Grupo Socialista) presentan una moción de censura contra el alcalde y apoyan otra candidatura firmada por todos ellos y encabezada por don Rodolfo León Martín, concejal socialista.

Dos días más tarde, el 13 de octubre, el secretario de Organización del PSOE-Canarias comunicó a la Secretaría General del Ayuntamiento de Tacoronte la expulsión provisional del partido de los concejales socialistas firmantes de la moción, señalando que el Grupo Municipal Socialista quedaría compuesto exclusivamente por el concejal no firmante de la misma, don Carlos Medina Dorta. Cinco días después, el 18 de octubre, se comunicó a la Secretaría General del Ayuntamiento la expulsión definitiva del partido político de dichos concejales.

El 22 de octubre se celebró la sesión en la que se aprobó la moción de censura, con once votos a favor, ocho en contra y dos abstenciones, siendo proclamado alcalde el candidato propuesto, don Rodolfo León Martín.

El alcalde censurado, don Álvaro Agustín Dávila González, interpuso recurso contencioso-administrativo por el procedimiento especial de protección de derechos fundamentales contra los acuerdos adoptados el 22 de octubre por la mesa de edad y el Pleno del Ayuntamiento de Tacoronte, mediante los que se dispuso la tramitación, sometimiento a votación y aprobación de la moción de censura, alegando la vulneración del art. 23.2 CE. La demanda se 
basaba en el incumplimiento de las exigencias de mayoría reforzada del art. 197.1.a) párr. tercero LOREG, y en la no verificación de dicha mayoría por la mesa de edad, tal y como preceptúa el subapdo. e) del artículo antedicho.

Según el demandante, era necesario un número de proponentes en el momento de la celebración del Pleno de, al menos, dieciséis miembros de la corporación, dado que a la mayoría absoluta ordinaria (once) había que sumar un número igual al de los firmantes de la moción que pasaron a la condición de no adscritos (según el art. 73.3 LRBRL) tras la expulsión del Grupo Municipal Socialista (cinco); quórum que no se cumplía.

Por su parte, la mesa de edad había considerado que las expulsiones no eran firmes y que la limitación de derechos de los representantes debía interpretarse, ex art. $23 \mathrm{CE}$, de manera restrictiva, por lo que concluyó que se cumplía el requisito de la mayoría requerida en el art. 197.1.a) LOREG.

El Juzgado de lo Contencioso-Administrativo núm. 4 de Santa Cruz de Tenerife dictó sentencia el 5 de febrero de 2014, en la que consideró que es causa de transfuguismo, subsumible en el párr. tercero del art. 197.1.a) LOREG, la pérdida de la condición de miembro de un partido político debida a una expulsión por razones disciplinarias, sin que el tenor literal de ese precepto («haya dejado de pertenecer por cualquier causa») pueda reducirse a supuestos de abandono voluntario del grupo político. De este modo, el juzgado acogió la pretensión de la parte actora (anulación de los acuerdos de 22 de octubre y restitución en su cargo de alcalde-presidente), al entender que se había visto vulnerado el art. 23.2 CE.

Contra esta sentencia interpusieron recurso de apelación ante el Tribunal Superior de Justicia de Canarias los cinco concejales expulsados del PSOE, alegando, entre otras cosas, la existencia de irregularidades en el procedimiento interno sancionatorio, la falta de firmeza de las expulsiones y su carácter no ejecutivo, así como la interpretación errónea del párr. tercero del art. 197.1.a) LOREG efectuada por la sentencia de instancia, dado que el mismo solo es aplicable a supuestos de abandono voluntario del grupo político, no así a casos de expulsión, menos aún cuando es la mayoría del grupo la que sostiene la moción.

Tras la tramitación del recurso, y dentro del plazo para dictar sentencia, la Sección segunda de la Sala de lo Contencioso-Administrativo del TSJ de Canarias acordó conferir un plazo de diez días a las partes y al Ministerio Fiscal para que, de conformidad con el art. 35.2 LOTC, formularan alegaciones sobre la pertinencia de plantear cuestión de inconstitucionalidad en relación con el art. 197.1.a) LOREG por infringir el art. 23.2 CE, «al privar del derecho al ejercicio del cargo público a los concejales disidentes con las instrucciones de los órganos directivos de sus partidos con ocasión de la votación de las 
mociones de censura, porque establece medidas equivalentes a la privación del derecho a voto en los plenos donde se decide la moción de censura».

Pese a que tanto las partes como el Ministerio Fiscal lo consideraran innecesario, la Sala del TSJ decide plantear la referida cuestión de inconstitucionalidad, cosa que hace mediante auto de 31 de julio de 2014, apoyándose en la siguientes consideración de fondo:

- La Sala entiende que la medida cuestionada del párr. tercero del art. 197.1.a) LOREG, establecida para combatir el transfuguismo, supone limitaciones al ejercicio del cargo público de los concejales que dejan de pertenecer a la formación política por la que concurrieron a las elecciones, pasando a la condición de no adscritos; limitaciones que afectan al núcleo esencial de la función representativa que constitucionalmente tienen atribuida (art. 23.2 CE); en concreto, a la facultad de control de la acción del Gobierno a través del apoyo de mociones de censura. $Y$ es que el incremento de la mayoría absoluta requerida con carácter general, según la Sala, convertiría la posibilidad de que dichos concejales patrocinen una moción de censura en algo meramente nominal, privando a sus apoyos de efecto alguno.

Admitida a trámite la cuestión de inconstitucionalidad por providencia de 3 de febrero de 2015, en el trámite de alegaciones el abogado del Estado solicita que se dicte sentencia desestimatoria de la misma, al entender que, dada la prevalencia del principio representativo y el límite de no defraudar la voluntad popular, en una democracia representativa «el derecho preponderante debe serlo el que se predique más directamente del titular de la soberanía, no tanto el del mandatario que la ejerce por cuenta de aquel. Ni tampoco el del partido político», que no sería sino una mera entidad instrumental del titular de la soberanía. Y esto es — según el abogado del Estado— justamente lo que persigue la norma controvertida [el art. 197.1.a) párrafo tercero LOREG], garantizar esa prevalencia, en cuanto que se encomienda a salvaguardar la voluntad colectiva del cuerpo electoral con una limitación razonable a la actuación de los concejales electos.

Por su parte, el fiscal general del Estado interesó asimismo la desestimación de la cuestión de inconstitucionalidad por entender que «la restricción impuesta en el precepto cuestionado no resulta desproporcionada, responde a un fin legítimo [...] y no resulta un impedimento artificial, sino relacionado con la adscripción política y adecuado y limitado al número de Concejales afectados». 
Finalmente, la representación procesal de don Álvaro Agustín Dávila González, el alcalde censurado, en sus alegaciones concluye que en el acto de la elección el ciudadano elector no deposita su confianza ni confiere su representación a una persona concreta, sino a una candidatura, máxime cuando rige en las elecciones municipales el sistema de lista cerrada o bloqueada; vinculación entre el candidato electo y la candidatura o lista electoral que no se diluye con ocasión de la elección, sino que se proyecta a lo largo de todo el mandato a través del grupo parlamentario o grupo político, siendo esto precisamente lo que persigue el precepto cuestionado, cuya constitucionalidad, por tanto, queda a salvo.

\section{FUNDAMENTOS JURÍDICOS DE LA STC 151/2017}

A la luz de todas las consideraciones y alegaciones efectuadas por la Sala del TSJ de Canarias, y demás partes concurrentes en el proceso, el Tribunal Constitucional entiende que

la duda de constitucionalidad deberá ceñirse [...] a la validez del párrafo tercero del apartado a) del artículo 197.1 LOREG en tanto que contiene el régimen jurídico que determina, a raíz de la repetida remisión de la letra e), que en el momento inmediatamente anterior a la votación de la moción de censura en el plenario debe satisfacerse el quórum del párrafo segundo de la misma letra a) cuando alguno de los concejales proponentes de la moción haya dejado de pertenecer, por cualquier causa, al grupo político municipal al que se adscribió al inicio de su mandato y, además, en función de la especialidad del párrafo segundo, siempre que no formara o haya formado parte del grupo político municipal al que pertenece el alcalde cuya censura se propone (FJ 2).

\section{LA DIMENSIÓN PASIVA DEL DERECHO FUNDAMENTAL DE PARTICIPACIÓN POLÍTICA DEL ART. 23.2 CE Y LA MOCIÓN DE CENSURA AL ALCALDE}

Como primer paso para verificar si la norma controvertida es o no constitucional, el Tribunal recuerda cuál es su doctrina acerca del art. 23.2 CE, precepto que reconoce el derecho de los ciudadanos a «acceder en condiciones de igualdad a las funciones y cargos públicos, con los requisitos que señalen las leyes». Según el Tribunal, aunque esta disposición se refiere únicamente de manera explícita al derecho a "acceder» a los cargos públicos, se ha de entender que implícitamente comprende también el derecho a «permanecer», en las 
mismas condiciones de igualdad y con los requisitos que señalen las leyes, en esos cargos públicos a los que se accedió (STC 5/1983, de 4 de febrero, FJ 3), «no pudiendo ser removido el cargo electo de los mismos si no es por causas y de acuerdo con procedimientos legalmente establecidos (STC 10/1983, de 21 de febrero, FJ 2)», así como el derecho a «ejercer o desempeñar» ese cargo público representativo conforme a lo previsto en las leyes (STC 246/2012, de 20 de diciembre, FJ 2). Derechos todos ellos que cuentan, además, con la "garantía de su perfeccionamiento en condiciones de igualdad y de acuerdo con los requisitos que señalen las leyes» (STC 298/2006, de 23 de octubre, FJ 6).

De esta forma, parece deducirse claramente de las palabras del Tribunal que el contenido completo de este derecho de participación política se encuentra claramente constreńido al respeto al derecho de igualdad y a la prohibición de discriminación consagrado en el art. $14 \mathrm{CE}$, limitación que, lógicamente, también afecta al legislador responsable de configurar el régimen jurídico de este derecho fundamental del art. 23.2 CE, esto es, de determinar cuáles son «los derechos y atribuciones de los representantes electos», derechos que, una vez creados, pasan a integrar el estatus propio del cargo, de manera que sus titulares, al amparo de este precepto constitucional, podrán reclamar su protección cuando consideren que los mismos han sido ilegítimamente constreñidos o ignorados por actos del poder público, incluidos los provenientes del propio órgano en que se integren (STC 36/2014, de 27 de febrero, FJ 5).

Sin embargo, eso no quiere decir que todo acto que violente tal régimen jurídico legalmente configurado suponga, per se, una violación del derecho fundamental del art. 23.2 CE, ya que «solo poseen relevancia constitucional los derechos o facultades atribuidos al representante que pertenezcan al núcleo de su función representativa» (SSTC 141/2007, de 18 de junio, FJ 3; 169/2009, de 9 de julio, FJ 2; 20/2011, de 14 de marzo, FJ 4; 117/2012, de 4 de junio, FJ 3, o 36/2014, de 27 de febrero. FJ 5).

Según el Tribunal, dentro de ese núcleo de la función representativa se encontrarían aquellas funciones que solo pueden ejercer los titulares del cargo público por ser la expresión del carácter representativo de la institución (STC 169/2009, de 9 de julio, FJ 3). En el ámbito local radicarían en "participar en la actividad de control del gobierno local y en las deliberaciones del pleno de la corporación; votar en los asuntos sometidos a este órgano; obtener la información necesaria para poder ejercer las facultades anteriores y, por último, participar en las comisiones informativas» (la STC 246/2012, de 20 de diciembre, FJ 7, las enuncia en su integridad). Funciones, todas ellas, que corresponden a todos los concejales, incluidos, por tanto, los «no adscritos» (FJ 3). 
Concretamente, la moción de censura, constitucionalmente prevista en relación con el Gobierno del Estado e incorporada por el legislador al ámbito local, representa una manifestación directa de este derecho de participación política previsto en el art. 23.2 CE, dado que es un «mecanismo de control y exigencia de responsabilidad política de los gobernantes por quienes les invistieron de la confianza para serlo». De hecho, según el Tribunal, la moción de censura aparece como «una pieza clave de la forma de gobierno local», que "configura el ius in officium, el estatus representativo de los concejales», al presentarse como un «instrumento de naturaleza híbrida, pues es, primordialmente, un medio de control y de exigencia de responsabilidad política por parte del pleno y, por tanto, un mecanismo de relación entre los órganos del gobierno municipal, pero, por otro lado, cuando prospera, implica a su vez una causa de cese del alcalde inicialmente designado - poniendo fin a la efectividad de la elección inicial-, con la subsiguiente proclamación de uno nuevo». En consecuencia, se ha de entender que la facultad de presentar una moción de censura forma parte del núcleo de la función representativa de los concejales, «siendo su regulación norma de desarrollo directo del artículo 23.2 CE» (STC 81/2012, de 18 de abril, FJ 3).

A partir de este razonamiento el Tribunal Constitucional concluye que el incremento sobre la mayoría absoluta dispuesto por el párr. tercero en relación con el segundo del art. 197.1.a) LOREG, que, de conformidad con el apdo. e) de este precepto, habrá de ser verificado por la mesa de edad al momento de proceder a dar lectura ante el Pleno de la moción de censura, supone una alteración para los concejales no adscritos del régimen ordinario de un derecho legalmente configurado como parte del núcleo de su función representativa, restringiéndolo abiertamente, al privar de efecto alguno a los apoyos que tales concejales no adscritos puedan ofrecer en la fase de iniciativa o propuesta de la moción, aunque no lo haga en la de votación (FJ 4).

Así las cosas, el paso siguiente — según el Tribunal— será determinar si esa disposición legal, con los efectos referidos, supone, sin más, una vulneración del art. 23.2 CE, «o si, por el contrario, cuenta con algún fundamento constitucionalmente admisible que la respalde por ser posible su armonización con el perfeccionamiento de la función representativa y la participación política en condiciones de igualdad (STC 298/2006, de 23 de octubre, FJ 6)».

A tal efecto, el Tribunal recuerda el contenido de los acuerdos antitransfuguismo a que nos referimos supra (epígrafe I), que se encuentran detrás de la reforma del art. 73.3 LRBRL por medio de la Ley 57/2003, de 16 de diciembre, de medidas para la modernización del gobierno local, mediante la que se introdujo la figura de los miembros no adscritos de las corporaciones locales, así como de la del controvertido art. 197 LOREG, por medio de la Ley 
Orgánica 2/2011, de 28 de enero, a través de la cual se trata de evitar la modificación de la voluntad política y la inestabilidad gubernamental, favoreciendo con ello la "regeneración democrática» (FJ 5).

Desde estas premisas, el Tribunal entiende que las restricciones o limitaciones impuestas a los concejales no adscritos por el precepto legal cuestionado responden a un "fin legítimo" (STC 71/1994, de 3 de marzo, FJ 6; y 9/2012, de 18 de enero, FJ 4), ya que la adscripción política de los representantes posee relevancia jurídica (STC 32/1985, de 6 de marzo, FJ 2), en tanto que el pluralismo político constituye un valor jurídico fundamental (art. 1.1 $\mathrm{CE})$ y que los partidos políticos, según dispone el art. $6 \mathrm{CE}$, son expresión de tal pluralismo, "concurren a la formación y manifestación de la voluntad popular y son instrumentos fundamentales para la participación política» de los ciudadanos.

Ahora bien, esas limitaciones o restricciones no pueden operar en contra de la «garantía de igualdad» sobre los derechos integrantes del ius in officium, garantía que además ha de armonizarse, de manera insoslayable, con la «libertad de mandato" —o prohibición de mandato imperativo, prevista en el art. 67.2 CE en relación con las Cortes Generales, pero extensible, según la propia jurisprudencia constitucional, a los representantes locales: STC 123/2017, de 2 de noviembre, FJ 3.B).b) —. Una libertad de mandato que construye la representación política a través de una vinculación directa o inmediata entre los representantes y los representados (STC 10/1983, de 21 de febrero, FJ 2), y que "supone la exclusión de todo sometimiento jurídico del representante, en cuanto tal, a voluntades políticas ajenas», incluidas las de «las organizaciones políticas o grupos políticos en que se integre o en cuyas listas hubiera concurrido a las elecciones» (FJ 6).

A partir de estos presupuestos, el Tribunal somete el precepto legal cuestionado [art. 197.1.a) párr. tercero LOREG] a juicio desde un prisma de igualdad y proporcionalidad de la diferencia de trato que el mismo contiene, lo que conlleva realizar el conocido triple juicio de idoneidad, necesidad y proporcionalidad en sentido estricto. Para el Tribunal, los dos primeros tests, el de idoneidad y el de necesidad, se superan sin problemas, en tanto que a través de la medida contenida en el precepto enjuiciado se consigue el fin perseguido por la misma (dificultar la exigencia de responsabilidad política y remoción del alcalde en la fase de promoción de la moción sin alterar el régimen de mayorías en la de votación, en tanto que en esta fase el voto de los concejales no adscritos computa igual que el de los adscritos).

Sin embargo, a juicio del Tribunal, el precepto enjuiciado no supera el test de proporcionalidad en sentido estricto, dado que, por un lado, «equipara, en la restricción del derecho, a todos los concejales que hayan dejado de 
pertenecer al grupo político municipal al que se adscribieron al inicio de su mandato ("por cualquier causa», dice la previsión legal)»; esto es, «no establece diferencia alguna en función de las circunstancias que puedan haber desencadenado el cese de dicha vinculación con el grupo político municipal, ni precisa el fundamento que permitiría asociar la disolución de la relación orgánica con el grupo político de origen y los fines singulares, relativos a la estabilidad municipal, que la norma debe intentar asegurar». Por otro lado, no distingue «en función de que la separación del grupo ataña o no a la vida de esa concreta corporación municipal». Asimismo, "tampoco valora el significado que eventualmente podría revelar la proporción de concejales que hayan expresado el desafecto o desacuerdo con el grupo político. Y no precisa, en fin, las razones que pudieran expresar un fraude de representación, ya sean políticas o de otra índole, y que pudieran estar en la base de ese resultado. Estima, antes bien, que cualquier disolución de ese nexo orgánico [...] es contraria en sí misma considerada a la estabilidad de la vida municipal o del gobierno local, equiparando el respeto de la voluntad popular y del gobierno local a la protección del alcalde que fue designado, cuando lo cierto es que la representación política, en democracia, es siempre colegiada y el alcalde, por ello, representa al ayuntamiento, perfilándose las mayorías de acuerdo a los pactos que se establecen. En definitiva, parte el legislador de que cualquier hipótesis de disolución del vínculo político es merecedora de una intervención que asegure la regeneración democrática, premisa esta que, ante la descrita falta de determinación normativa que lo fundamente, no puede aceptarse» por parte del Tribunal.

Además, dicha restricción opera con base en un criterio estrictamente subjetivo (desvinculación de los concejales del grupo político municipal al que se adscribieron al inicio de su mandato), careciendo por completo del fundamento objetivo, «entendido como obligado soporte constitucional frente a una medida restrictiva de ius in officium y del mandato libre en el ejercicio del cargo representativo».

Por último, «el legislador soslaya que la aplicación de la norma no solo puede dificultar sino incluso hacer del todo inviable en una pluralidad de escenarios la propia tramitación de aquella iniciativa de control del gobierno municipal, vetando la exigencia de responsabilidad y la remoción del alcalde».

En consecuencia, el Tribunal concluye que el art. 23.2 CE ha sido violado por el precepto cuestionado, en tanto que la anomalía conocida como «transfuguismo», que ha incidido negativamente en el sistema democrático y representativo,

no puede intervenirse por el legislador con restricciones al ius in officium (STC 9/2012) que impacten en el ejercicio natural del cargo público al amparo de la 
libertad de mandato con base en razones asociadas, sin adjetivos, a la vinculación orgánica o política, sin fundamentos añadidos. Sencillamente porque no es cierto que la desvinculación orgánica o política del grupo de origen desestabilice por defecto o sin excepción la vida municipal o modifique la voluntad popular. Así lo demuestran casos como el que está en el origen de este procedimiento constitucional, en el que la razón de la expulsión de los concejales socialistas fue por completo ajena a la vida municipal de Tacoronte, al tener que ver con cuestiones orgánicas y pactos suscritos por su partido político en ámbitos territoriales que lo excedían (FJ 7).

\section{LA INCONSTITUCIONALIDAD, CON NULIDAD DIFERIDA, DEL ART. 197.1.A) PÁRR. TERCERO LOREG}

Con fundamento en las consideraciones precedentes, el Tribunal Constitucional declara la inconstitucionalidad del art. 197.1.a) párr. tercero LOREG, pero "únicamente en cuanto determina, a raíz de la reiterada remisión de la letra e), que en el momento inmediatamente anterior a la votación de la moción de censura en el plenario debe satisfacerse el quórum del párrafo segundo de la letra a)», sin que proceda,

a tenor de lo previsto en el artículo 39.1 LOTC, extender esa declaración de inconstitucionalidad por conexión o consecuencia a los restantes supuestos y fases del procedimiento regulados en la letra a) del artículo 197.1 LOREG, como tampoco, globalmente, al inciso «constatando para poder seguir con su tramitación que en ese mismo momento se mantienen los requisitos exigidos en los tres párrafos del apartado a)», contenido en la letra e) de ese artículo, al regularse en ellos situaciones adicionales que no han sido objeto de examen en este pronunciamiento y que no concurren en el supuesto de hecho examinado en el proceso del que trae origen la presente cuestión de inconstitucionalidad.

Además, en este caso, el Tribunal matiza el efecto característico e inmediato de la declaración de inconstitucionalidad, esto es, la nulidad de la norma cuestionada (art. 39.1 LOTC), por entender que tal «anulación [...] podría generar alteraciones en procedimientos de exigencia de responsabilidad política en curso por la ausencia de un régimen jurídico alternativo y respetuoso con la Constitución que cohoneste el principio de igualdad en el ejercicio de las funciones representativas y la prevención de los efectos perversos causados por el transfuguismo en los legítimos fines declarados por la norma». Por esta razón, según el Tribunal, en este supuesto, «la 
nulidad derivada de la declaración de inconstitucionalidad debe quedar diferida hasta la convocatoria de un nuevo proceso de elecciones locales, [...] periodo de tiempo en el que el legislador podrá proceder, en su caso, a sustituir la norma declarada nula observando el contenido de este pronunciamiento» (FJ 8).

\section{VALORACIÓN CRÍTICA DE LA STC 151/2017}

Prácticamente desde el mismo momento en que la democracia local comenzó su andadura tras la aprobación de la Constitución en 1978, con la celebración de las primeras elecciones municipales, el 3 de abril de 1979, es posible encontrar supuestos de abandono por parte de un concejal de su grupo político de procedencia. Esta circunstancia acabaría teniendo consecuencias directas sobre la estabilidad de los Gobiernos locales, una vez que, según hemos visto supra, fue aceptada por la jurisdicción contencioso-administrativa la posibilidad de la destitución de alcaldes, cuando así lo acordasen, al menos, dos tercios de los miembros de la corporación, aplicando por analogía la normativa ya existente en relación con las diputaciones (Ley 39/1978, de 17 de julio) con base en el principio contrarius actus (Sanz Pérez, 2012: 91).

Esta práctica, poco tiempo después, se vería elevada a ley, mediante el reconocimiento de la moción de censura en la legislación básica de régimen local aprobada en 1985 y su correspondiente remisión a la LOREG del mismo año. Eso explica que desde muy temprano el Tribunal Constitucional tuviera que enfrentarse a la cuestión relativa a la titularidad del cargo público una vez que un concejal abandona su grupo político (reflejo en lo institucional del correspondiente abandono del partido político por el que se presentó a las elecciones).

Así, en la Sentencia 10/1983, de 2 de febrero, al enjuiciar el art. 11.7 de la referida Ley 39/1978, el Tribunal deja clara la doctrina clásica de la representación política, cuando afirma que

al otorgar al partido la facultad de privar al representante de su condición cuando lo expulsa de su propio seno [...] el precepto infringe [...], de manera absolutamente frontal, el derecho de los ciudadanos a participar en los asuntos públicos a través de representantes. Una vez elegidos, los representantes no lo son de quienes los votaron, sino de todo el cuerpo electoral, y titulares, por tanto, de una función pública a la que no pueden poner término decisiones de entidades que no son órganos del Estado, en el sentido más amplio del término (FJ 4). 
Ese tipo de actuaciones (el abandono por parte de un concejal de su grupo político, que desemboca en una remoción del alcalde a través de una moción de censura), pese a que no sean muy frecuentes, sin embargo, desde un comienzo, son vistas con recelo tanto por los propios partidos políticos, como por la ciudadanía, al entender que con ellas no solo se traiciona una elemental regla de lealtad política al partido de origen, el mismo que posibilitó que esa persona pudiera presentarse por su lista y fuera elegido concejal, sino que, además, ofrece una imagen de los Gobiernos locales muy negativa, vinculada al «tráfico de votos»o al intercambio de favores, a la corrupción, en definitiva, que acaba erosionando la confianza de los ciudadanos en el propio sistema democrático representativo. Y ello, muchas veces, con independencia de cuál haya sido la razón de fondo que ha llevado a ese concreto concejal a abandonar su partido o grupo político.

La misma caracterización de este fenómeno como "transfuguismo», un término cargado de un fuerte sentido peyorativo, ofrece una buena idea de ello, incluso mucho antes de que el primer acuerdo entre las fuerzas políticas para combatir este fenómeno, en 1998, tuviera lugar ${ }^{16}$.

Según hemos tenido ocasión de ver, el legislador solo reaccionaría frente a esta práctica considerada indeseable años después de que el primer pacto antitransfuguismo (renovado en 2000) fuera aprobado. Hasta 2003 no se introducirá, por medio de la Ley 57/2003, de 16 de diciembre, de medidas para la modernización del Gobierno local, la figura de los llamados «concejales no adscritos» en el art. 73.3 $\mathrm{LRBRL}^{17}$, entendiendo por tales aquellos que no se integren «en el grupo político que constituya la formación electoral por

16 Buena muestra de ello es que con anterioridad a esa fecha es posible encontrar, tanto en la jurisprudencia como en numerosos trabajos académicos, referencias críticas a esta práctica. A este último respecto, valga por todos Esteban Alonso (1990: 8), quien sostiene que «la esencia misma del transfuguismo en Espańa se basa en el deseo, en ciertos políticos, de mejorar sus expectativas de futuro sin que, en la mayor parte de las ocasiones, intervengan auténticas motivaciones ideológicas». Con posterioridad al acuerdo de 1998 (y sus revisiones de 2000 y 2006), un completo estudio del fenómeno del transfuguismo desde diversas perspectivas (incluida la comparada, la autonómica y la jurisprudencial) en Santolaya y Corona (2009).

17 No obstante, hay que tener en cuenta que con anterioridad algunas legislaciones autonómicas ya habían previsto esta figura: Ley 7/1999, de 9 de abril, de Administración Local de Aragón (art. 111); Ley 2/2003, de 11 de marzo, de Administración Local de la Comunidad de Madrid (art. 32); Decreto Legislativo 2/2003, de 28 de abril, por el que se aprueba el texto refundido de la Ley municipal y de régimen local de Cataluña (art. 50); Ley 1/2003, de 3 de marzo, de la Administración Local de La Rioja (art. 122). 
la que fueron elegidos o que abandonen su grupo de procedencia $»^{18}$. Un precepto ciertamente controvertido, pues, entre otras cosas, en tanto norma básica que es, debería haber cumplido con su función de establecer un mínimo común denominador, un estatus común, para todos los miembros de las corporaciones locales, cosa que no hace (Alonso Mas, 2005: 129).

Por otro lado, y pese a la frecuente identificación que se realiza, lo cierto es que "tránsfuga» y "concejal no adscrito", de acuerdo con la regulación vigente, no son exactamente lo mismo ${ }^{19}$. Como acabamos de ver, de conformidad con el art. 73.3. LRBRL, "concejales no adscritos" son aquellos que «no se integren en el grupo político que constituya la formación electoral por

En opinión de Alonso Mas (2005: 99), esta normativa, de dudosa constitucionalidad al "contravenir la legislación básica estatal entonces vigente, que obligaba a la integración en grupos de todos los concejales», con la aprobación de la ley de medidas para la modernización del gobierno local habría quedado sanada «de manera sobrevenida", en la medida en que su contenido se ajuste a las nuevas bases estatales.

18 Con anterioridad a la reforma de 2003, los concejales que abandonaban su grupo político se integraban en el Grupo Mixto, del que cabe entender que a partir de ese momento solo formarán parte quienes, desde el principio, integren una formación política que carezca de suficiente número de miembros para constituirse en grupo independiente. Véase Alonso Mas (2005: 96).

19 Así lo entiende Català i Bas (2014: 46 y ss.), para quien la figura del concejal no adscrito, aunque fue creada para hacer frente a la patología del transfuguismo, de acuerdo con el art. 73.3 LRBRL, «hace referencia exclusivamente a una razón objetiva y aséptica, como es el lugar político en que se ubica un concejal, sin referencia alguna al elemento subjetivo que [...] es el determinante en el transfuguismo: la motivación de esa ubicación y, en concreto, la deslealtad política».

En el mismo sentido, De la Torre Martínez (2018: 112), para quien «la calificación de concejal no adscrito implica un régimen jurídico definido en la legislación básica estatal, en la autonómica y en la normativa de los Municipios, que no tiene por qué coincidir en la de concejal tránsfuga”, en la medida en que la condición de este» — según afirma esta misma autora en la nota al pie de página número 6- «implica una calificación política otorgada por la Comisión de Seguimiento con fundamento en el Pacto Antitránsfuga de 2006 y conlleva la adopción de ciertas medidas que vienen a castigar al concejal tránsfuga, previstas de cara a las futuras elecciones».

En sentido similar, Alonso Mas (2005: 129) sostiene que los supuestos comprendidos en la figura del concejal no adscrito regulada en el art. 73.3 LRBRL «no responden, al menos todos ellos, al transfuguismo; además de que esta conducta no siempre responderá a móviles ilegítimos». En su opinión, «el problema no es tanto el transfuguismo como el sistema electoral, de listas cerradas y bloqueadas».

Muy crítico también con el art. 73.3 LRBRL se muestra, entre otros, Galán Galán (2004: 59 y ss.). 
la que fueron elegidos o que abandonen su grupo de procedencia $»^{20}$. Por su parte, si tomamos como referencia la definición de «tránsfuga» contenida en la II adenda al acuerdo antitransfuguismo, de 23 de mayo de $2006^{21}$, comprobaremos que la misma no es plenamente coincidente con la de concejal no adscrito. Y esta definición, aunque tiene simplemente el valor del texto en el que se encuentra inserta, un mero acuerdo político, parece que es, sin embargo, la que se «esconde» detrás de las referencias que los párrs. segundo y tercero del art. 197.1.a) LOREG hacen a los concejales proponentes de una moción de censura que formaran o hayan formado parte del grupo político municipal al que pertenece el alcalde cuya censura se propone, o que hayan dejado de

20 El estatuto jurídico del concejal no adscrito no es fácil de aprehender en sus precisos contornos, pues el mismo se ha configurado, en buena medida, por obra jurisprudencial (entre otras muchas, STC 214/1989, de 21 de diciembre), dado que la LRBRL no contiene una regulación completa de cuáles son sus derechos y facultades, remitiéndose al Reglamento Orgánico de cada municipio. Además, también la legislación autonómica puede contribuir, en el ámbito de sus competencias, a configurarlo.

Un estudio muy completo del régimen jurídico de los concejales no adscritos tras la Ley 57/2003 en De la Torre Martínez (2014: capítulos IV y V).

De acuerdo con la jurisprudencia constitucional, el derecho de representación (art. 23.2 CE) es un derecho individual que corresponde a cada representante (concejal, en este caso) y que no se encuentra sometido a mandato imperativo alguno (incluido, por supuesto, el de los partidos políticos), lo que significa, básicamente, que el concejal no adscrito es titular de todos los derechos que derivan de su condición de representante público; es decir, que sus derechos individuales de participación política no se verán modificados por el hecho de que cambie de condición, pasando de concejal adscrito a no adscrito. Por lo demás, la mayor parte de las sentencias se dedican a determinar el alcance de los siguientes derechos de los concejales no adscritos: el derecho de participación política del art. $23 \mathrm{CE}$ (con sus diferentes manifestaciones, vinculadas o no al núcleo de la función representativa, como el derecho a participar en las comisiones informativas con voz y con voto) y los derechos económicos y políticos (no vinculados al núcleo de la función representativa). Véanse, entre otras, las SSTC 20/2011, de 14 de marzo; 52/2011, de 28 de abril; 53/2011, de 28 de abril; 54/2011, de 3 de mayo; 55/2011, de 3 de mayo; 56/2011, de 3 de mayo; 101/2011, de 20 de junio; 102/2011, de 20 de junio; 103/2011, de 20 de junio; 112/2011, de 4 de julio; 113/2011, de 4 de julio; 114/2011, de 4 de julio; 115/2011, de 4 de julio; 116/2011, de 4 de julio; 122/2011, de 12 de julio; 129/2011, de 18 de julio; 130/2011, de 18 de julio; 131/2011, de 18 de julio; 9/2012, de 18 de enero; 14/2012, de 6 de febrero; 30/2012, de 1 de marzo; 246/2012, de 20 de diciembre; 10/2013, de 28 de enero; y 103/2013, de 25 de abril; así como las SSTS de 18 de mayo de 2012; de 5 de junio de 2012; de 3 de julio de 2012.

21 Véase supra: nota al pie de página número 13. 
pertenecer, por cualquier causa, al grupo político municipal al que se adscribieron al inicio de su mandato.

De este modo, la definición que se ofrece de los concejales no adscritos en el art. 73.3 LRBRL es más descriptiva, en la medida en que, por un lado, se dedica a identificar quiénes son estos, y, por el otro, establece un límite al alcance de sus "derechos económicos y políticos», que "no podrán ser superiores a los que les hubiesen correspondido de permanecer en el grupo de procedencia, y [que] se ejercerán en la forma que determine el reglamento orgánico de cada corporación» (párr. segundo) ${ }^{22}$.

Por su parte, la referencia a los concejales proponentes de una moción de censura de los párrs. segundo y tercero del art. 197.1.a) LOREG, además de no ser, según acabamos de ver, plenamente coincidente con la del art. 73.3 LRBRL, conlleva una carga negativa mucho más evidente, en la medida en que su sola condición de tales sitúa a estos representantes en una peor posición a la hora de ejercer la facultad de exigencia de responsabilidad del Gobierno municipal a través de la moción de censura al alcalde. En buena lógica, parecería que los concejales a que se refiere el art. 197.1.a) LOREG son los considerados «tránsfugas». $\mathrm{Y}$, sin embargo, quizás eso sea mucho suponer, pues podría haber motivaciones por parte de alguno/s de esos concejales que no fueran merecedoras de reproche, sino todo lo contrario, si es que entendemos - como resulta, por otro lado, lógico- que la decisión de un concejal de abandonar su grupo político no siempre puede ser considerada una «traición» (término usado en el acuerdo antitransfuguismo), sino consecuencia lógica, por ejemplo, de un distanciamiento del grupo político del programa con el que el partido correspondiente se presentó a las elecciones. El problema es que esta posibilidad no se contempla en el referido pacto antitransfuguismo. Es

22 El régimen de los concejales no adscritos, como se ha apuntado ya, podrá variar de una comunidad autónoma a otra y dentro de cada una de ellas de un municipio a otro, dado que no solo hay que tener en cuenta lo dispuesto en la normativa estatal básica (LRBRL), sino también lo que establezca la legislación autonómica de desarrollo (SSTC 214/1989, de 21 de diciembre; y 103/2013, de 25 de abril) y cada Reglamento Orgánico municipal, dentro de los márgenes que aquella disponga. El Tribunal Constitucional llegó a entender que las efectivas limitaciones que cabe derivar de este art. 73.3 LRBRL para los derechos de los concejales no adscritos no suponen una restricción del núcleo de su función representativa, pues no cualquier afectación del estatus jurídico del representante trae consigo una vulneración del derecho fundamental previsto en el art. 23.2 CE, sino solo aquella que limiten los derechos de control, deliberación, votación en Pleno e información (SSTC 9/2012, de 18 de enero; y 30/2012, de 1 de marzo). Véase De la Torre Martínez (2014: 150). 
más, se deja en manos de la propia formación política aclarar las posibles dudas que pudiera haber acerca de si algún miembro de su lista y/o grupo político ha incurrido en transfuguismo por haberse apartado de la disciplina de partido.

Esto explica las críticas que despertó esta regulación, pues el art. 197.1.a) LOREG, con sus graves consecuencias en términos jurídico-fundamentales, se aplica tanto a los concejales no adscritos tránsfugas como a aquellos otros que, en los términos vistos del acuerdo, no pueden ser considerados tránsfugas. Y de ahí que la STC 151/2017, de 21 de diciembre, tenga que abordar inevitablemente esta cuestión, fallando como lo hace, esto es, reconociendo que no todo abandono (o expulsión) de un concejal de su grupo político de procedencia constituye una manifestación de transfuguismo, ni busca, en consecuencia, alterar la voluntad popular y/o desestabilizar la vida municipal ${ }^{23}$. Razón que lleva al Tribunal a entender que el art. 197.1.a) párr. tercero LOREG supone una vulneración del derecho fundamental a la participación política reconocido en el art. 23.2 CE, en tanto que exige una mayoría reforzada de proponentes de la moción de censura cuando entre ellos haya algún concejal que pertenezca o haya dejado de pertenecer al grupo político del alcalde o que no esté adscrito a ninguno.

Por más que este derecho fundamental precise de ser configurado legalmente, el mismo posee un contenido característico, que es el que se habría visto vulnerado por la disposición impugnada, en concreto, el llamado ius in officium, que - según el propio Tribunal Constitucional- comprende no solo el derecho a acceder al cargo público en condiciones de igualdad, sino también a permanecer en él y a ejercer las facultades propias del mismo, legalmente reconocidas, sin perturbaciones ilegítimas, lo que, a su vez, entronca con la prohibición de mandato imperativo (STC 10/1983, de 21 de febrero, FJ 3).

La dimensión pasiva del derecho de participación política, que es la amparada por el art. 23.2 CE, se traduce en el ejercicio de la función representativa, que en sus aspectos nucleares, como ha recordado el Tribunal

23 En esta misma línea de argumentación se encuentra Alonso Mas (2005: 122), cuando se pregunta «si resulta adecuado y proporcionado el recorte de los derechos de participación de los concejales por el hecho de no estar adscritos a ningún grupo. Adecuación no la hay, desde luego, cuando la falta de pertenencia a un grupo se deba no a una decisión del concejal, sino a su expulsión, ya que el concejal puede ver recortada su participación por una decisión que él no ha adoptado; incluso, a la misma conclusión hay que llegar cuando el abandono del partido se haya debido a una legítima causa». 
Constitucional en múltiples ocasiones, está encomendada en exclusiva a quienes ostentan tales cargos públicos,

por ser la expresión del carácter representativo de la institución (SSTC 141/2007, FJ 3 y 169/2009, FJ 3, por todas) y de la que no pueden ser privados incluso en el caso de que los titulares del cargo público hayan optado por abandonar el grupo político de procedencia (SSTC 5/1983, FJ 4; 185/1993, FJ 5 y 298/2006, FJ 7, por todas). Por esta razón, entre las funciones que pertenecen al núcleo inherente a la función representativa que constitucionalmente corresponde a los miembros de una corporación local se encuentran, en todo caso, la de participar en la actividad de control del gobierno local, la de participar en las deliberaciones del Pleno de la corporación, la de votar en los asuntos sometidos a votación en este órgano, así como el derecho a obtener la información necesaria para poder ejercer las anteriores (SSTC 169/2009, FJ 3; 20/2011, FJ 4; y $9 / 2012, \mathrm{FJ} 4)^{24}$.

Así pues, estaba diáfanamente claro que, de conformidad con la jurisprudencia constitucional existente a la fecha de dictarse la STC 151/2017, el 21 de diciembre de 2017, el derecho de representación política es un derecho fundamental que corresponde, en este caso, a todos los concejales, incluidos, por supuesto, los no adscritos, y que no se encuentra sometido a mandato imperativo alguno (del partido o del grupo político correspondiente). La participación en la moción de censura es, por tanto, un derecho individual de cada concejal como representante público que es; no se trata de una iniciativa que deba formularse a través de los grupos políticos. La diferencia es trascendental, pues explica que el endurecimiento de las condiciones de ejercicio a los no adscritos no pueda sino ser entendido como una limitación injustificable del núcleo de su función representativa (Alonso Mas, 2018: 165).

Aunque no se llegue a decir con estos precisos términos en la sentencia, la clave de la argumentación se encuentra en el hecho de que el control del Gobierno municipal mediante el ejercicio de la moción de censura forma parte del núcleo esencial del derecho fundamental de participación política del art. 23.2 CE, derecho que corresponde a todos y cada uno de los concejales, estén o no adscritos. Siendo esto así, la conclusión no puede ser otra que aquella a la que llega el Tribunal: el incremento del número de concejales proponentes de la moción de censura en igual número al de concejales no adscritos (o pertenecientes al grupo político del alcalde a censurar), verificable no solo en el mismo momento de la propuesta sino también en el instante previo

24 (STC 246/2012, de 20 de diciembre, FJ 7). 
a la votación en el Pleno, tal y como prevén los apdos. a) y e) del art. 197.1 LOREG, priva a estos de la posibilidad de ejercer, como los demás concejales, aquella facultad de control gubernamental, por más que la razón que se ofrezca para justificar tales medidas sea una tan plausible como la lucha contra el transfuguismo, a fin de asegurar el no torcimiento de la voluntad popular y la estabilidad municipal, que se vería en riesgo mediante la modificación de las mayorías de gobierno hasta ese momento existentes.

Si el titular del derecho fundamental de participación política en su dimensión pasiva (art. 23.2 CE) es el cargo electo (diputado, senador o concejal), la importancia del partido político por el que se presente a las elecciones (o del grupo parlamentario o político en que se integre una vez elegido), aun siendo políticamente relevante, en tanto que a través de tales partidos o grupos se articula el pluralismo político y se organiza, en buena medida, el funcionamiento de los órganos (cámaras legislativas o plenos de ayuntamientos) en que se integran, no puede servir de justificación para privar a aquel de la libertad que necesariamente le corresponde en el ejercicio de su función representativa, ni, lógicamente, para colocarle en una posición desigual a este respecto en relación con el resto de cargos electos, por el solo hecho de que se haya desvinculado de aquel partido o grupo político.

Por otro lado, y aunque el Tribunal no se refiera a ello en la sentencia objeto de este comentario, tampoco se puede ignorar que el concejal es titular del derecho fundamental a la libertad ideológica (art. 16.1 CE), tal y como sí afirmó el propio Tribunal, entre otras, en su Sentencia 101/1983, así como del derecho de asociación (art. 22.1 CE), del que también forma parte, en su vertiente negativa, el derecho a no asociarse o a abandonar una asociación a la que se pertenece, incluyendo aquí, lógicamente, a los partidos políticos, pues aunque, dada la trascendencia política de sus funciones, los mismos pueden poseer una regulación distinta de la general de las asociaciones, en todo caso la misma ha de respetar el contenido esencial del derecho de asociación (STC 48/2003, de 12 de marzo), del que forma parte la referida libertad negativa. En consecuencia, resultaría difícilmente justificable que la ley atribuyera a la decisión de abandonar un partido político «efectos jurídicos desfavorables, ya que eso es tanto como penalizar el ejercicio de aquel derecho» ${ }^{25}$. Razonamiento este que se podría extender igualmente al abandono de un grupo político, en tanto que reflejo institucional del partido político.

25 En este mismo sentido, como afirmó el Tribunal Supremo en la sentencia de 23 de enero de 1995, si los cambios de adscripción política de un representante público no se hallan prohibidos en la Constitución, carece por completo de justificación objetiva y razonable penalizar esos cambios. Véase Alonso Mas (2005: notas al pie de página 50 y 53). 
En otro orden de cosas, y aunque tampoco el Tribunal haga referencia a ello en la sentencia analizada, resulta muy cuestionable que, de acuerdo con lo previsto en el apdo. e) del art. 197.1 LOREG, la mayoría absoluta requerida para la presentación de la moción de censura se pueda convertir en mayoría reforzada si los concejales que la presentaron, antes de proceder a su votación, son expulsados de su partido, convirtiéndose así en no adscritos. Parece que el legislador ha previsto en el apdo. e) una condición que deja completamente en manos de los partidos políticos determinar, en último término, cuál es la mayoría que se precisa para que pueda procederse a la votación de una moción de censura, algo que, por afectar al núcleo del derecho fundamental del art. 23.2 CE, carece de justificación alguna.

Por otra parte, la garantía de igualdad a que apela el art. 23.2 CE, concreción del principio de igualdad contenido en el art. $14 \mathrm{CE}$, y, por tanto, lex specialis $^{26}$, constituye también un límite infranqueable para el legislador: la diferenciación que se pueda establecer entre los concejales adscritos y los que no lo estén en el específico campo del control del Gobierno a través de la moción de censura con el fin de asegurar los objetivos mencionados (estabilidad gubernamental, respeto a la voluntad popular, etc.) no puede afectar al núcleo de la función representativa ${ }^{27}$. En directa sintonía con ello, el Tribunal Constitucional acentúa la importancia de que la actuación del representante (concejal, en este caso) no esté sujeta a mandato ajeno alguno que provenga de los propios electores o del partido o grupo político en que aquel esté o haya estado integrado.

A la vista de los argumentos aportados hasta el momento por el Tribunal (y de aquellos otros aquí enunciados a los que podría haber acudido), su razonamiento podría haberse detenido en este punto, en la medida en que disponía ya de elementos de juicio suficientes para ofrecer una respuesta a la cuestión planteada. Sin embargo, en su enjuiciamiento de la constitucionalidad del art. 197.1.a) párr. tercero LOREG, el Tribunal decide someter este precepto al conocido control de proporcionalidad, con su triple juicio de

26 Así lo ha reconocido el Tribunal Constitucional en múltiples sentencias. Valgan por todas las SSTC 50/1986, de 23 de abril; 84/1987, de 19 de mayo; 73/1994, de 3 de marzo; 83/2000, de 27 de marzo, y 107/2003, de 2 de junio.

27 En este sentido, son muchos los autores que se mostraron muy críticos con la reforma de 2011 de la LOREG, y, en particular, con la exigencia de esta mayoría más amplia o reforzada, por no resistir un escrutinio a la luz de los derechos de igualdad o no discriminación y de participación política. Valga por todos Chueca y Gavara (2011); y Delgado del Rincón (2012: 347), quien habla de «desnaturalización de la propia institución de la moción de censura». 
idoneidad, necesidad y proporcionalidad en sentido estricto, para verificar si existe alguna causa que justifique la restricción que impone el precepto cuestionado. Tras hacerlo, llega a la conclusión de que tal medida limitativa de las facultades de los concejales no adscritos contenida en ese precepto supera los dos primeros tests, pero no así el tercero, en tanto que aquel precepto equipara a todos los concejales que hayan dejado de pertenecer al grupo político al que se encontraban adscritos al comienzo de su mandato, sin diferenciar, por tanto, en razón de la causa que les ha llevado a la toma de esa decisión ${ }^{28}$.

En definitiva, parece que para el Tribunal lo determinante es el motivo que ha llevado a un concejal a abandonar su grupo político de origen (o a votar en un sentido u otro, si es que pertenece o ha pertenecido al grupo político del alcalde a censurar), dando por supuesto que existen motivos «buenos» y otros que no lo son (los que cabría encuadrar dentro de la categoría de «transfuguismo», porque persigan, por motivos espurios — corrupción, etc.—, la desestabilización de la vida municipal y la modificación de la voluntad popular). De este modo, cabría deducir del razonamiento del Tribunal que si el legislador hubiera diferenciado objetivamente entre unos y otros motivos, el precepto cuestionado habría superado sin problemas el control de constitucionalidad; pero al no hacerlo así, por considerar que cualquier ruptura de la vinculación entre el concejal y su grupo político es merecedora de una restricción de sus facultades representativas (de su ius in officium), no cabe sino afirmar la tacha de inconstitucionalidad de tal norma.

En el fondo, el Tribunal, pese a que sostenga lo contrario, está asumiendo con este argumento que el legislador puede definir una serie de motivos que justificarían la limitación del ius in officium del representante. Bastaría con que los mismos vinieran definidos en términos objetivos en la ley ${ }^{29}$. El problema es que eso conllevaría una constricción, imposible de delimitar, de la función representativa, al tiempo que podría colocar al aplicador de la ley en la inaceptable posición de «juzgador de

28 Lo que es objeto de crítica por el magistrado Cándido Conde-Pumpido en su voto particular, al que se adhiere el magistrado Alfredo Montoya, pues, a su juicio, no se lleva a cabo un verdadero juicio de proporcionalidad en sentido estricto, esto es, una ponderación de beneficios y perjuicios. Sobre la improcedencia de utilizar el juicio de proporcionalidad en un caso como este, poniendo el acento en la insuficiente justificación del juicio de idoneidad y necesidad, así como en la inexistencia de un análisis de costes-ventajas, característico del juicio de proporcionalidad en sentido estricto, véase Alonso Mas (2018).

29 Hacia esta misma idea apunta Alonso Mas (2018: 167). 
intenciones ${ }^{30}$, lo que más allá de otros graves problemas ${ }^{31}$ chocaría de frente con los derechos y libertades fundamentales reconocido en el art. 16 $\mathrm{CE}$, de los que, por supuesto, también es titular el representante público.

Por estas mismas razones, tampoco se puede compartir el alcance de la declaración de inconstitucionalidad acordada por el Tribunal Constitucional. Según este, procede declarar la inconstitucionalidad del precepto cuestionado [art. 149.1.a) párr. tercero LOREG]

únicamente en cuanto determina, a raíz de la reiterada remisión de la letra e), que en el momento inmediatamente anterior a la votación de la moción de censura en el plenario debe satisfacerse el quórum del párrafo segundo de la letra a), siempre que alguno de los concejales proponentes de la moción haya dejado de pertenecer, por cualquier causa, al grupo político municipal al que se adscribió al inicio de su mandato y, además, en función de la especialidad del citado párrafo segundo, siempre que no forme o haya formado parte del grupo político municipal al que pertenece el alcalde cuya censura se propone.

Esa declaración de inconstitucionalidad no se extendería, ex art. 39.1 LOTC,

por conexión o consecuencia a los restantes supuestos y fases del procedimiento regulados en la letra a) del artículo 197.1 LOREG, como tampoco, globalmente, al inciso "constatando para poder seguir con su tramitación que en ese mismo momento se mantienen los requisitos exigidos en los tres párrafos del apartado a)», contenido en la letra e) de ese artículo, al regularse en ellos situaciones adicionales que no han sido objeto de examen en este pronunciamiento y que no concurren en el supuesto de hecho examinado en el proceso del que trae origen la presente cuestión de inconstitucionalidad.

No se alcanza a comprender bien la limitación de esta declaración de inconstitucionalidad, porque, de acuerdo con el razonamiento aquí sostenido, la afectación del ius in officium prevista tanto en el párr. segundo como en el

30 No otra cosa parece deducirse del reproche que el Tribunal hace al legislador porque la norma impugnada «no precisa [...] las razones que pudieran expresar un fraude de representación, ya sean políticas o de otra índole» (FJ 7).

31 Entre los que no ocupa un lugar menor «la dificultad de diseñar correctamente aquellos supuestos en que efectivamente concurra fraude a la representación", como reconoce Alonso Mas (2018: nota al pie de página 59), pese a que la misma se muestre favorable al establecimiento de límites objetivos. 
tercero del art. 197.1.a) LOREG carece de justificación posible. Y es que, en efecto, en ambos párrafos se establece una restricción a las facultades de control y exigencia de responsabilidad del Gobierno municipal vía moción de censura que corresponden a los concejales no adscritos, o a los que formaran parte del grupo municipal al que pertenezca el alcalde cuya censura se propone, que desvirtúan el ejercicio de la función representativa constitucionalmente garantizada como manifestación directa del derecho fundamental del art. 23.2 CE, y que, en consecuencia, no superan el juicio de constitucionalidad.

Finalmente, llama también la atención que el Tribunal no anude el pronunciamiento de inconstitucionalidad con la nulidad inmediata del precepto cuestionado, tal y como dispone con carácter general el art. 39.1 LOTC. Por el contrario, considera el Tribunal que esta

debe ser matizada en este caso concreto ya que la anulación de la disposición cuestionada podría generar alteraciones en procedimientos de exigencia de responsabilidad política en curso por la ausencia de un régimen jurídico alternativo y respetuoso con la Constitución que cohoneste el principio de igualdad en el ejercicio de las funciones representativas y la prevención de los efectos perversos causados por el transfuguismo en los legítimos fines declarados por la norma. Por ello, la nulidad derivada de la declaración de inconstitucionalidad debe quedar diferida hasta la convocatoria de un nuevo proceso de elecciones locales, de conformidad con lo previsto en el artículo 42.3 de la Ley Orgánica 5/1985, de 19 de junio, del régimen electoral general, periodo de tiempo en el que el legislador podrá proceder, en su caso, a sustituir la norma declarada nula observando el contenido de este pronunciamiento.

Tal y como señala la magistrada Encarnación Roca en su voto particular concurrente, no se alcanza a comprender bien, entre otras cosas porque la sentencia no lo explica,

cuáles son los derechos, intereses, bienes o valores que tienen una relevancia constitucional tal que llevan a modular los efectos de nulidad propios de una sentencia de inconstitucionalidad. No cualquier valor o interés justifica el aplazamiento de la eficacia de la nulidad del precepto legal declarado inconstitucional. Por lo tanto, no ha quedado aquí acreditado que haya tal incidencia que justifique el mantenimiento de la vigencia de una norma inconstitucional durante casi ańo y medio [...]. Y tampoco se valora que la pervivencia de la regulación implica el sacrificio temporal del derecho fundamental reconocido en el artículo 23.2 CE. 
Parece que el Tribunal «teme» que la inexistencia de un régimen jurídico alternativo que ofrezca una respuesta adecuada a los supuestos de transfuguismo pueda provocar situaciones indeseables, sin importarle tanto que pueda pervivir en el ordenamiento durante un largo de período de tiempo una norma que el mismo ha declarado inconstitucional por ser contraria, nada menos, que al contenido esencial de un derecho fundamental ${ }^{32}$. Además, como apunta igualmente la Magistrada Roca, tampoco parece razonable que el propio Tribunal seńale el camino al legislador para aprobar la regulación que ha de sustituir a la declarada inconstitucional, en tanto que estaría asumiendo una función que en absoluto le corresponde.

De manera parcialmente coincidente, el magistrado Andrés Ollero en su voto particular entiende que «la obvia inconstitucionalidad de la medida ha de acarrear su nulidad e inmediata expulsión del ordenamiento jurídico». Lo que no le impide reconocer que «la situación volvería así a ser la existente antes de la cuestionada reforma legal, con los ya señalados riesgos de transfuguismo a los que el legislador, en el plazo que considere oportuno, habrá de hacer frente recurriendo a criterios no personalizados sino de carácter objetivo", como, por ejemplo, «optar por una mayoría basada en criterios objetivos, como las de dos tercios o tres quintos»"

Indudablemente, esta alternativa propuesta por el magistrado Ollero tendría la ventaja de convertir en criterio objetivo lo que ahora no lo es, en la medida en que ya no importaría la adscripción, o falta de ella, de los concejales proponentes de la moción de censura, colocándolos a todos en una

32 Como señala Lomo Casanueva (2018: 6), «esta decisión [...] va provocar que el TSJ de Canarias tenga que aplicar una norma que el propio TC acaba de declarar inconstitucional. La incongruencia es máxima». Y — cabría añadir — la inseguridad jurídica que se genera es, asimismo, muy elevada.

33 Esta idea, si bien limitada a aquellas mociones de censura apoyadas por concejales no adscritos, ya está presente en el trabajo de Fernández Hernández (2016: 9 y ss.). En su opinión, «el legislador podría haber optado por otras fórmulas que limitaran pero no excluyeran el derecho de los no adscritos a presentar censuras. Así podría haber regulado una mayoría de dos tercios a aquellas mociones de censuras apoyadas por tránsfugas.

Estos dos tercios tienen ventajas sobre la mayoría reforzada ya que no se cambia el tamaño del órgano, el porcentaje de dos tercios siempre es el mismo con independencia del número de concejales tránsfugas que la apoyen, es aritméticamente posible alcanzarla y no se comete la aberración jurídica de contar dos veces al concejal para alcanzar la reforzada (ya que se le cuenta dentro de la absoluta y se le vuelve indebidamente a contar de nuevo como tránsfuga)».

En sentido similar se pronuncia Lomo Casanueva (2018: 5). 
posición de igualdad, como es la demandada por el art. 23.2 CE. No obstante, también podrían surgir dudas sobre la constitucionalidad de una medida como esta, en tanto que la misma, al elevar tan sensiblemente el quórum de procedibilidad, podría conllevar una restricción igualmente inaceptable de las funciones representativas que integran el contenido del derecho de participación política en su vertiente pasiva.

Tampoco se acaba de entender por qué cabe establecer dos quórums procedimentalmente diferenciados, para la presentación y ulterior tramitación previa a la votación, de la moción de censura, cuando, en realidad, ambos condicionan de igual modo la posibilidad de que esta prospere o no. Crítica esta, por cierto, que cabría hacer también a la fundamentación de la sentencia, en la medida en que en ella el Tribunal trata de diferenciar, como si fuesen cosas perfectamente separables, uno y otro quórum (el de procedibilidad y el de votación), cuando, en realidad, la mayor exigencia del primero condiciona absolutamente la menor gravedad del segundo, sin que se pueda, entonces, sostener, como hace el Tribunal, que

la duda de constitucionalidad deba ceñirse solo a la validez del párrafo tercero del apartado a) del art. 197.1 LOREG en tanto que contiene el régimen jurídico que determina, a raíz de la repetida remisión de la letra e), que en el momento inmediatamente anterior a la votación de la moción de censura en el plenario debe satisfacerse el quórum del párrafo segundo de la misma letra a) cuando alguno de los concejales proponentes de la moción haya dejado de pertenecer, por cualquier causa, al grupo político municipal al que se adscribió al inicio de su mandato y, además, en función de la especialidad del párrafo segundo, siempre que no formara o haya formado parte del grupo político municipal al que pertenece el alcalde cuya censura se propone.

La pretensión de deslindar el quórum primero de procedibilidad (presentación de la moción de censura) del segundo (constatación del mismo por parte de la mesa de edad en el momento previo a la votación de la moción en el Pleno), para concluir que la duda de constitucionalidad deberá ceñirse solo a este último, no deja de ser una injustificable arbitrariedad, pues la inconstitucionalidad del segundo quórum no es sino una prolongación de la inconstitucionalidad del primero, por restringir de manera indebida el ius in officium del representante. Nada hubiera impedido al Tribunal Constitucional, ex art. 39.1 LOTC, declarar inconstitucional lo que es tal, contribuyendo así a depurar el ordenamiento jurídico de disposiciones contrarias a la Constitución ${ }^{34}$.

34 En este mismo sentido, Lomo Casanueva (2018: 6). 


\section{CONCLUSIÓN}

En la sentencia objeto de este comentario se pone de relieve cómo el régimen jurídico propio de un derecho fundamental, el de participación política en su vertiente pasiva (art. 23. CE), construido sobre la clásica teoría de la representación, en virtud de la cual el representante no está sujeto a mandato imperativo alguno, puede entrar en tensión, en la llamada democracia de partidos, con una realidad difícil de ignorar, a saber, que el voto de los electores va dirigido, con carácter general, a una determinada formación política, de forma que cuando alguno de los representantes elegido en su lista se aparta de su grupo político de origen y cambia el sentido de su voto, en un momento tan crítico como el que representa una moción de censura, puede ser entendido como una "traición», que se suele caracterizar bajo el término de "transfuguismo»" La ciudadanía, animada muchas veces por unos medios de comunicación que suelen poner el foco de atención sobre esos supuestos, por más excepcionales que sean, puede acabar percibiendo que una práctica como esa significa una quiebra de la voluntad popular, que puede acabar desestabilizando el Gobierno municipal ${ }^{36}$.

El intento de reaccionar frente a ella, a través de acuerdos políticos suscritos entre los propios partidos políticos, responde, por tanto, a un fin legítimo. Sin embargo, la cuestión problemática que aquí se discute apunta hacia la cuestionada constitucionalidad de las medidas adoptadas por el legislador para responder a tales situaciones, que por más que persigan un fin legítimo, en sí mismas no pueden ser contrarias al contenido esencial de un derecho fundamental, en este caso, el del art. 23.2 CE, del que forma parte el llamado ius in officium, en tanto que manifestación de la función representativa.

$\mathrm{Y}$ es precisamente esta prueba la que no supera el precepto impugnado [art. 197.1a) párr. tercero LOREG], por prever unas medidas que resultan contrarias a una facultad que forma parte de la esencia de la función representativa, la de control y exigencia de responsabilidad del Gobierno municipal a

35 A esta misma idea apunta De la Torre Martínez (2014: 179), cuando señala que «tras el examen del régimen jurídico de los concejales no adscritos se dilucida la lucha entre dos principios constitucionales, como se ha declarado recientemente en la STC 246/2012: de una parte, la garantía del pluralismo político y la adscripción política de los concejales teniendo como eje fundamental los partidos políticos y su influencia (artículo 1.1 y $6 \mathrm{CE}$ ), y de otra, el mandato representativo de los concejales, que son elegidos por los ciudadanos de conformidad con el artículo $23 \mathrm{CE}$.

36 O, dicho de otro modo, en palabras del magistrado Conde-Pumpido en su voto particular a la STC 151/2017, «no hay duda de que la legitimidad del gobierno local y, con ello, del propio sistema democrático se puede resentir a los ojos de los ciudadanos». 
través de la moción de censura, en la medida en que establece unas condiciones de ejercicio de la misma claramente desiguales para un tipo de concejales que para otros, a partir de un dato, la permanencia o distanciamiento del grupo político de origen, que, por más relevancia política que pueda tener, es insuficiente para justificar esa desigualdad ${ }^{37}$.

A esa conclusión, acertada, en mi opinión, llega el Tribunal Constitucional en su Sentencia 151/2017, de 21 de diciembre, si bien los argumentos que emplea para tal fin no se pueden compartir en su totalidad, de igual modo que tampoco se puede compartir el sentido limitado del fallo y la no vinculación de la inconstitucionalidad de la norma a su nulidad inmediata.

\section{Bibliografía}

Alonso Mas, M. J. (2005). El discutible régimen jurídico de los concejales no adscritos. Revista de Administración Pública, 168, 95-130.

— (2018). Los miembros no adscritos de las entidades locales ante la formulación de la moción de censura: una discutible aplicación del principio de proporcionalidad. Revista de Administración Pública, 206, 149-178. Disponible en: https://doi. org/10.18042/cepc/rap.206.05.

Català i Bas, A. H. (2014). Transfuguismo y régimen jurídico de los concejales no adscritos. ¿Puede, y debe, el Derecho sancionar la deslealtad política? Revista Española de Derecho Constitucional, 101, 43-77.

Chueca Rodríguez, R. y Gavara de Cara, J. C. (2011). La reforma de la Ley Orgánica del Régimen electoral General. Madrid: Centro de Estudios Políticos y Constitucionales.

De la Torre Martínez, L. (2018). De nuevo sobre los concejales no adscritos (a propósito de la sentencia del tribunal constitucional 151/2017, de 21 de diciembre). Revista de Estudios de la Administración Local y Autonómica, 9, 110-127.

37 Dicho de modo más directo, como lo hace Lomo Casanueva (2018: 5 y ss.), «la regulación contenida en el art.197.1.a) no es más que un artificio jurídico que se dirige a privar de valor a la firma/voto de los concejales "no adscritos", de tal manera que como nos decía el Auto de 31/7/2014 del TSJ Canarias, la posibilidad de que estos apoyen la moción es "meramente nominal y priva a sus apoyos de efecto alguno". Y ese puro artificio es un simple y burdo fraude de ley, dirigido a impedir [...] un resultado prohibido por el ordenamiento jurídico, privar de valor la firma/voto de un concejal electo, circunstancia que afecta de una manera directa al núcleo esencial de su estatus jurídico que pertenece individualmente al mismo, y no al partido. Esta limitación supone con ello una vulneración del derecho fundamental a la participación política, pues la regulación contenida en el precepto produce el mismo resultado que si en el mismo se fijase que los concejales no adscritos no tienen derecho a suscribir ni votar una moción de censura». 
- (2014). El estatuto jurídico de los concejales no adscritos. (Serie Debates locales; 4). Madrid; Barcelona: Fundación Democracia y Gobierno Local.

Delgado del Rincón, L. E. (2012). La 'parlamentarización' de la forma de gobierno local: la reforma de la LOREG sobre la moción de censura y la cuestión de confianza local y su incidencia en el derecho de los concejales a ejercer un cargo público representativo. Revista de Administración Pública, 189, 331-364.

Elías Méndez, C. (2005). La moción de censura en España y Alemania (Estado, Länder y Comunidades Autónomas). Madrid: Congreso de los Diputados.

Esteban Alonso, J. de (1990). El fenómeno español del transfuguismo político y la jurisprudencia constitucional. Revista de Estudios Políticos, 70, 7-32.

Fernández Hernández, O. M. (2016). La moción de censura modificada por la LO 2/2011, de 28 de enero: aplicación práctica y posible inconstitucionalidad. El Consultor de los ayuntamientos y de los juzgados: Revista técnica especializada en administración local y justicia municipal, 11, 1289-1297.

Galán Galán, A. (2004). El Reglamento Orgánico Local. Madrid: INAP.

Lomo Casanueva, T. (2018). Moción de censura en los entes locales: ¡el fin de las limitaciones de los concejales no adscritos o tránsfugas? STC 151/2017, de 21 de diciembre de 2017. Actualidad Administrativa, 4.

Ortega Montoro, R. J. (2018). La moción de censura local tras la Sentencia del Tribunal Constitucional núm. 151/2017, de 21 de diciembre. Revista de Derecho Local, 1 de enero de 2018. Disponible en: https://bit.ly/2XEKKey.

Rebollo Puig, M. (1985). La moción de censura en la Administración local. Revista de Estudios de la Administración Local y Autonómica, 227, 459-486. Disponible en: https://doi. org/10.24965/reala.vi227.8429.

Sánchez Calvache, A. y Lomo Casanueva, T. (2017). La moción de censura en las entidades locales. Consultor de los ayuntamientos y de los juzgados: Revista técnica especializada en administración local y justicia municipal, 18, 2192-2215.

Santolaya Machetti, P. (2001). Crónica de un fracaso jurídico (y político): la moción de censura de los alcaldes. En R. Morodo Leoncio y P. De Vega García (coords.). Estudios de Teoría del Estado y de Derecho constitucional en homenaje a Pablo Lucas Verdú (pp. 28012832), tomo IV. Madrid: Universidad Complutense de Madrid; Universidad Nacional Autónoma de México.

Santolaya Machetti, P. y Corona Ferrero, J. M. (dirs.) (2009). Transfuguismo politico: escenarios y respuestas, Madrid: Civitas.

Sanz Pérez, Á. L. (2012). Régimen local versus régimen electoral: la moción de censura al alcalde. Revista Aranzadi Doctrinal, 4, 89-96.

Simón Yarza, F. (2015). La moción de censura: ¿constructiva u 'obstructiva'? Revista Española de Derecho Constitucional, 103, 87-109.

Torres Muro, I. (2017). La moción de censura constructiva. Una respuesta alemana, y espańola, a la inestabilidad gubernamental. Foro (Revista de ciencias jurídicas y sociales), 20 (1), 279-292. Disponible en: https://doi.org/10.5209/FORO.57537.

Vírgala Foruria, E. (1988). La moción de censura en la Constitución de 1978 (y en la historia del parlamentarismo español). Madrid: Centro de Estudios Constitucionales. 